Marquette University

e-Publications@Marquette

Theology Faculty Research and Publications

Theology, Department of

$1-1-2010$

Reading Kant from a Catholic Horizon: Ethics and the Anthropology of Grace

Philip J. Rossi

Marquette University, philip.rossi@marquette.edu

Published version. Theological Studies, Vol. 71, (2010): 79-100. Publisher Link. (C) 2010 Theological Studies, Inc. Used with permission. 


\title{
READING KANT FROM A CATHOLIC HORIZON: ETHICS AND THE ANTHROPOLOGY OF GRACE
}

\author{
PHILIP J. Rossi, S.J.
}

\begin{abstract}
For two centuries Catholic philosophers and theologians have generally treated Immanuel Kant's critical philosophy as incompatible with principles fundamental to Catholic accounts of the human condition in relation to God. This article argues that contemporary scholarship_particularly about the role of anthropological concerns in the critical project - indicates that Kant's understanding of finite human freedom provides a basis for Catholic theology to engage his thinking positively in the articulation of a theology of grace for humanity's postmodern context.
\end{abstract}

$\mathrm{T}$ HIS ARTICLE ARGUES FOR a renewed Catholic theological engagement with the critical philosophy of Immanuel Kant (1724-1804). It advances this argument within the context of a larger thesis about the theological presuppositions that function within Kant's work, as well as within interpretations both friend and foe of his philosophy have given to his project of "critique." This thesis is that key differences in the ways both philosophers and theologians have understood central elements of the critical philosophy frequently exhibit divergent "theological horizons" against which these interpreters have explicitly or, more often, implicitly framed their rendering of the issues, arguments, and concepts in Kant's texts. Such theological horizons function, in the first instance, on Kant's own part, inasmuch as the critical philosophy articulates its account of human finitude over against a robust sense of transcendence. For Kant, fundamental to the conceptual space of the human-i.e., to the articulation of an account of what distinctively constitutes our humanity-is the orien-

PhILIP J. RossI, S.J., received his Ph.D. from the University of Texas, Austin, and is professor of theology at Marquette University, Milwaukee. He specializes in Kant, philosophical theology/philosophy of religion, and ethics. Among his recent publications are: "Radical Evil and Kant's 'Metaphysic of Permanent Rupture,"” in Kant's Anatomy of Evil (2010); "Sojourners, Guests, and Strangers: The Church as Enactment of the Hospitality of God," Questions liturgiques - Liturgical Questions 90 (2009); and "Seeing Good in a World of Suffering: Incarnation as God's Transforming Vision," in Godhead Here in Hiding: Incarnation and the History of Human Suffering (2009). In progress are a monograph on Kant's anthropology of human finite freedom as a resource for a postmodern Catholic anthropology of grace, and writings on the theological appropriation of the philosophical work of Charles Taylor, Susan Neiman, and George Steiner. 
tation of that space to transcendence as it delimits the contours of our properly human finitude. In affirming human finitude-for which his trope is "the limits of reason"-as marked out by radical difference from transcendence, Kant stands within the theological horizon to which the reflective traditions of Abrahamic monotheism have oriented themselves in affirming "God" as the proper name for the transcendence humanity encounters in radical Otherness.

Yet theological horizons also operate from the side of Kant's readers; within many of these horizons, however, Kant's way of locating the conceptual space of the human by its orientation to transcendence can no longer be taken as given. Kant himself may very well have framed his account of the human by reference to transcendence that we unavoidably must think, even as he contended that it exceeds our capacity to think transcendence "as" an "object," i.e., to articulate it cognitively. Whatever he may have held negatively about the possibility of humans rendering transcendence cognitively intelligible, a human orientation to transcendence still remains fundamental to his theological horizon. His readers, however, particularly in the unfolding course of late modernity and its aftermath, have increasingly found themselves within various forms of what Charles Taylor has termed an "immanent frame."

Here the theological horizon has shifted from what it was for Kant, so that the conceptual space of the human no longer seems to require, as condition for its intelligibility, an orientation to transcendence. So even as some readers continue to frame their understanding of the critical philosophy against a theological horizon akin to Kant's, in which transcendence provides a condition of intelligibility for the human and finite, others read it from the seemingly "atheological" horizons provided by the immanent frame of much contemporary intellectual culture. ${ }^{2}$ In both cases, these horizons significantly affect how Kant's interpreters then construe both the larger trajectories of his work as well as the central concepts and arguments he offers as he moves through the construction of the critical project. In neither case, moreover, is a sympathetic or hostile reading of the critical project necessarily a function of the extent to which one stands within or outside a theological horizon comparable to Kant's. Some of Kant's fiercest opponents include those who affirm with him a robust form of divine transcendence, while some of those who stand within the immanent frame revere Kant as 'one of its founders. One aim of this article is

${ }^{1}$ Charles Taylor, A Secular Age (Cambridge, Mass: Belknap, 2007); chapter 15 contains an extensive discussion of "the immanent frame."

${ }^{2}$ The extent to which Kant's philosophy-or at least the reception of Kant's philosophy-bears responsibility for the emergence of the immanent frame is an important issue that will not be directly treated here. See note 6 , below, for some initial coordinates for such a discussion. 
to suggest that recent work on Kant may require both friend and foe alike to reconsider where his work is most aptly positioned with respect to fundamental questions about how the human is to be construed in relation to the divine, particularly as that relation is theologically rendered in terms of "grace."

The first two sections of this article will serve to explicate and illustrate this larger thesis, without, however, attempting to mount a full-scale argument on its behalf. ${ }^{3}$ Against the background of this thesis, my goal in the last two sections is then to explore some consequences of reading Kant from a horizon delimited by a set of concerns that historically have been characteristic of Catholic theological inquiry, especially with respect to conditions for human receptivity to grace. In particular, I hope first to show how key elements of a Catholic theological anthropology-in contrast, for instance, to a Calvinist or Lutheran one-provide a distinctive lens for reading Kant's accounts of human moral agency and its role in the attainment of the destiny of humankind. I will then briefly discuss how reading Kant through such a lens has import not only for an appropriate Catholic theological engagement with Kant's work but also for developing a more adequate understanding of the properly philosophical mode of his own enterprise. Reading Kant from a Catholic theological horizon not only helps bring into sharper focus issues key to his philosophical enterprise of critique, but it also enriches conversations on matters central to articulating an ever more adequate theological understanding of human reality as it stands in graced relation to God.

\section{THEOLOGICAL HORIZONS}

My understanding of "theological horizon" can be most readily displayed by looking first at one that functions on Kant's own side. Perhaps one of the few matters on which almost all readers of Kant are likely to agree is that he is persistent in raising questions both at and about the limits of human agency and inquiry. In the course of his relentless pursuit of these questions, he constantly brings to the surface a range of possibilities for construing the constitutive elements of what it is to be human, particularly as these elements function to delimit humanity's unique status in the cosmos as the intersection of freedom and nature. The possibilities he then frames most pointedly for construing the human frequently concern how, as such a unique intersection of freedom and nature, humanity then stands in its finitude with respect to the divine. As a result, the

${ }^{3}$ For a more extensive treatment of this thesis see Philip J. Rossi, S.J., "Reading Kant through Theological Spectacles," in Kant and the New Philosophy of Religion, ed. Chris Firestone and Stephen Palmquist (Bloomington: Indiana University, 2006) 107-23. 
"theological horizon" that functions on Kant's side arises precisely with respect to his characterization of the human as finite. It is limned, not surprisingly, by the anthropological question, "What is man?" which he articulated as recapitulating the three focal questions for the enterprise of critique: "What can I know? What ought I do? What may I hope for?" Although this horizon frames an inquiry that Kant takes pains to keep stringently philosophical, it nonetheless draws that inquiry toward concerns similar to those that contemporary theology explores under the heading of "theological anthropology," namely, the shape of the human as it is to be viewed within the context of the reality of the divine. Thus, to the extent that Kant's inquiry works from within a "theological horizon," that horizon is first framed anthropologically. He takes the question of how the human stands with respect to the divine to arise-and to arise ineluctably - from our unique human status in the cosmos, even as he wrestles with the intractability of articulating such a relationship across what he understands to be the radical difference between the human and the divine. ${ }^{5}$

If I am correct in characterizing Kant's own theological horizon by reference to his fundamental anthropological concerns with the character and shape of human finitude, this by itself does not render the character of that horizon, as well as the concerns that give rise to it, obvious or unproblematic to the theological reader. A central point of my larger thesis, moreover, is that insofar as our own reading of Kant's texts also requires us to frame responses to that famous set of questions about knowledge, action, and hope, we will find that their framing places us, at least implic-

${ }^{4}$ Immanuel Kant, Lectures on Logic, trans. and ed. J. Michael Young (New York: Cambridge University, 1992) 538. The first three questions, without the anthropological gloss, are posed in The Critique of Pure Reason, trans. Allen W. Wood and Paul Guyer, Cambridge Edition of the Works of Immanuel Kant (New York: Cambridge University, 1998), "The Canon of Pure Reason" 677 (A805/B833 in the 1st and 2nd German editions).

${ }^{5}$ Susan Neiman makes this point in a provocative way: "Of the many distinctions Kant took wisdom and sanity to depend on drawing, none was deeper than the distinction between God and the rest of us. Kant reminds us as often as possible of all that God can do and we cannot. Nobody in the history of philosophy was more aware of the number of ways that we can forget it. He was equally conscious of the temptation to idolatry, the alternative route to confusing God with other beings. Kant's relentless determination to trace the ways we forget our finitude was matched only by his awareness that such forgetting was natural" (Evil in Modern Thought: An Alternative History of Philosophy [Princeton, N.J.: Princeton University, 2002] 75). The centrality that Neiman gives to this distinction suggests that Kant's work still bears the mark of what Robert Sokolowski calls "the Christian distinction" between God and the world that is "different from distinctions made within the word" (The God of Faith and Reason [Washington: Catholic University of America, 1995] xiv). 
itly, within a horizon in which the finitude of the anthropological implicates the theological. Within this horizon questions about the nature and meaning of the human find themselves almost inevitably referenced to questions about the nature and meaning of the divine to which the human stands in contrast-even, it should be noted, in the case of those who can envision a theological horizon to be constituted only in terms of the complete absence of the divine. ${ }^{6}$

Kant's theological horizon stands in a mutually refractive relation to that of his readers, so we cannot simply doff our own spectacles to don (only) Kant's. More pointedly for my main argument, it may very well be that some of the crucial differences that have internally demarcated Christian theological traditions from one another with respect to their anthropology, especially as these have been articulated since the Reformation, provide a helpful set of markers for tracing the theological horizons that function to shape different readings of Kant.?

An instructive instance of how such differences function in reading Kant can be found in recent treatments of the question of the extent to which his understanding of "grace" should be taken to be Pelagian with respect to his construal of the capacities of human moral agency. Jacqueline Mariña's essay, "Kant on Grace: A Reply to his Critics," 8 provides a useful road map for this dispute, inasmuch as her analysis helps locate at least two different theological horizons from which Kant's discussions of grace in

${ }^{6}$ This claim raises at least two crucial questions that are far too large for this article to address. One is how to read Kant's texts with respect to the various modern forms of theoretical and practical atheism: is he, wittingly or unwittingly complicit in legitimating the contemporary intellectual culture of unbelief? A case for charging Kant with such complicity can be found in Gordon E. Michalson Jr., Kant and the Problem of God (Oxford: Blackwell, 1999). The other is whether it is proper to consider atheism-particularly in its modern and contemporary formsas itself articulating a position that, at least ironically, is "theological." For some historical background useful for the consideration of this second question, see Michael J. Buckley, At the Origins of Modern Atheism (New Haven, Conn.: Yale University, 1987) and Denying and Disclosing God: The Ambiguous Progress of Modern Atheism (New Haven, Conn.: Yale University, 2004). Charles Taylor's $A$ Secular Age may also be read as an extended argument that theological questions are unavoidable even with the immanent frames of late modernity; see especially chapters $16-18$.

7 These markers, shaped from within the context of the Reformation, are not the only ones relevant to delimiting the anthropological differences treated in this article, but they are particularly important to the extent that articulating them points out the particular conceptual care needed in distinguishing, on the one hand, questions about the limitations consequent upon human finitude and contingency and, on the other, questions about the limitations consequent upon human complicity in sin and evil.

8 Jacqueline Mariña, "Kant on Grace: A Reply to His Critics," Religious Studies 33 (1997) 379-400. 
relation to human agency can be read. The first, within which grace is primarily (or even exclusively) construed as "divine aid" in the face of a human incapacity to turn away from sin, places the reading of Kant's treatment of moral regeneration in a text such as Religion within the Boundaries of Mere Reason ${ }^{9}$ within a theological horizon delimited by an articulation of the problem of justification as it has been classically focused by the Reformation: How am I, a helpless sinner, ever to be saved? When translated into the concepts of Kant's account of human moral freedom, this problematic becomes one of finding logical space for acts of divine mercy and graciousness to function within the ambit of the exercise of an individual human autonomy that has been flawed by a willful inversion of one's incentives for choice. Within this horizon, one has little option but to take as Pelagian Kant's emphasis on the individual human agent's responsibility to adopt the categorical imperative as the supreme maxim of choice for extricating oneself from "radical evil." Grace and mercy, understood as unmerited, have no function in a field of action in which agents bear strict accountability for the good or the evil, intended or done, and for the way they thus make themselves good or evil. The regeneration of the moral agent must be the moral agent's own doing. Within this context, it is not surprising that two important defenders of the view that Kant is Pelagian, Gordon Michalson and Nicholas Wolterstorff, whom Mariña addresses in her essay, are authors whose work shows considerable familiarity with key issues about the status and stance of the human in the face of the divine-i.e., with issues of theological anthropology-that have preoccupied certain strands of Protestant theology since the Reformation. ${ }^{10}$

${ }^{9}$ This is the translation of the title of Kant's 1793 Die Religion innnerhalb der Grenzen der bloßen Vernunft used in Religion and Rational Theology, Cambridge Edition of the Works of Immanuel Kant, trans. and ed. Allen W. Wood and George Di Giovanni (New York: Cambridge University, 1996). There are currently 13 volumes in this edition, which, on completion, is likely to serve as the standard locus for English language access to Kant's work.

${ }^{10}$ In addition to their writings on Kant, Gordon E. Michalson Jr. has published articles on Bultmann ("Bultmann's Metaphysical Dualism," Religion in Life 44 [1975] 453-61) and Pannenberg ("Pannenberg on the Resurrection and Historical Method," Scottish Journal of Theology 33 [1980] 345-59); as well as a monograph on Lessing (Lessing's 'Ugly Ditch': A Study of Theology and History [University Park: Pennsylvania State University, 1985]). Nicholas Wolterstorff has published articles on Calvin and Lockẻ on the assurance of faith ("The Assurance of Faith," Faith and Philosophy 7 [1990] 396-417); Calvin on sacraments ("Not Presence But Action: Calvin on Sacraments," Perspectives 9 [1994] 16-22) and on social injustice ("The Wounds of God: Calvin's Theology of Social Injustice," Reformed Journal 37 [1987] 14-22); Barth on evil ("Barth on Evil," Faith and Philosophy 13 [1996] 584-608); as well as a monograph that has Barth as a main interlocutor (Divine Discourse: Philosophical Reflections on the Claim That God Speaks [New York: Cambridge University, 1995]). 
Reading Kant against a theological horizon formed by reference to the Reformation problematic of justification thus supports a view that if grace functions at all in his account of human moral agency, it must do so first and foremost (and, perhaps, exclusively) as an exercise of divine aid to initiate or assist the moral regeneration of the agent enmeshed in the "radical evil" of her own making. In contrast to this, Mariña proposes that another understanding of grace is primary for Kant, namely, that "[his] most general and principal conception of grace ... can be defined simply as 'God's unmerited favour', to which the individual can relate both practically and existentially."11 Mariña argues that Kant envisions a universal function for grace in constituting the unconditioned moral worth of humans, whereby God establishes a relation with us "before any act on our part." 12 Grace thus operates in the relational context constitutive of human moral agency so that "the very possibility of our doing good rests on grace." ${ }^{13}$ In consequence, grace operates at a structural level of the human even more fundamental than that implicated in "moral regeneration": grace functions principally as the fundamental form of divine relation to the human that is prior to any moment of "divine aid" with respect to particular human activities. ${ }^{14}$

Mariña sets her argument for the primacy of this more general notion of grace in the context of a theological horizon that stands in explicit contrast to that delimited solely by the problem of justification. She first contends that "this general notion of grace is not simply a response to the problem of radical evil. If it were merely this, the problem of evil would define the contours of that which is needed to solve it, namely grace." ${ }^{15}$ Within this larger context, moreover, the notion of grace has crucial anthropological ramifications: "more importantly, the upshot of the theological concept of grace has more to do with our posture vis-à-vis God than with the metaphysical subtleties of divine freedom. ... The divine/human relationship is established by God with us before any act on our part, and this means that all that we can do is to be receptive of God's grace."16 The "horizon of grace" in which Mariña places Kant is thus one in which the role of grace is primarily relational with respect to the very constitution of human agency

${ }^{11}$ Mariña, "Kant on Grace" 385.

${ }^{12}$ Ibid. 383 , italics original.

13 Ibid. 399.

14 A crucial consequence of this shift is that it offers a mode of construing divine activity "in" and "on" the world that need not be "interventionist." See David Burrell, "Divine Action and Human Freedom in the Context of Creation"; and Kathryn Tanner, "Human Freedom, Human Sin and God the Creator," in The God Who Acts: Philosophical and Theological Explorations, ed. Thomas F. Tracy (University Park: Pennsylvania State University, 1994) 101-9, 111-35.

${ }^{15}$ Mariña, "Kant on Grace" 385, italics original.

${ }^{16}$ Ibid. 383 , italics original. 
rather than primarily or even exclusively forensic with respect to the restoration of an "original" justification that has been lost. ${ }^{17}$

Mariña's account of Kant's treatment of grace consequently places his discussion of grace as the "divine aid" that functions in moral regeneration within a more general concept of grace for which "there is an intrinsic connection between the universality of the moral law, grounded in the absolute worth of all rational creatures, and the concept of unmerited grace. Only if we think of a holy will as gracious to all rational creatures, and as therefore universal in scope, can we preserve a significant sense of the unmerited character of grace." 18 This, Mariña concludes, places Kant's account within a theological horizon of grace that, marked deeply by Augustinianism, not only "strays far from the Reformation view which sought to comprehend justification in forensic terms" but also places "[Kant's] doctrine of grace ... much closer to Rome."19

\section{A CATHOLIC KANT?}

From the perspective typical of the Catholic neo-Scholastic thinkingepitomized by Cardinal Désiré-Joseph Mercier's analysis in his 1891 essay "The Two Critiques of Kant"-that well into the 20th century took Kant to be a subjectivist, Mariña's placement of Kant as close to Rome in any theological matter would undoubtedly come as a surprise. ${ }^{20}$ It should be less of a surprise - though hardly uncontroversial - to other readers of

17 The proposal that Mariña makes here may also be understood as a shift to a perspective that views grace first of all in relation to the contingency and finitude of creation. It thus opens possibilities for enlarging the locus of the significance of Kant's work for theological anthropology beyond issues of justification and soteriology by repositioning it in reference to creation and thus to what Sokolowski terms "the Christian distinction" (see n. 5 above).

${ }^{18}$ Mariña, "Kant on Grace" 384.

${ }^{19}$ Ibid. 400. For another perspective on the relation of Kant's account of moral agency and radical evil to both Catholic and Protestant treatments of original sin, see Robert Merrihew Adams, "Original Sin: A Study in the Interaction of Philosophy and Theology," The Question of Christian Philosophy Today, ed. Francis J. Ambrisio (New York: Fordham University, 1999) 80-110.

${ }^{20}$ Déseré Joseph Mercier, "The Two Critiques of Kant," in Cardinal Mercier's Philosophical Essays: A Study in Neo-Thomism, ed. David A. Boileau (Leuven: Peeters, 2002) 137-50. Mercier, prior to becoming cardinal archbishop of Malines (1906), "had a long and successful career as a university lecturer" and founded the Institute for Higher Philosophical Studies at Louvain in 1894, which became a major center for neo-Thomism in the 20th century. His own interests focused on epistemology, and he "defended the universal and necessary judgments of the intellect against the positivism of his day and what he took to be the subjectivism of Kant" (Gerald A. McCool, The Neo-Thomists [Milwaukee: Marquette University, 1994] 36-37). Another typical instance of a subjectivist reading of Kant from an early 20 th-century neo-Thomist perspective can be found in the entry, 
Kant who recognize that, as a philosopher, Kant is not concerned to measure his account of theological matters by reference to the interpretation of any particular Christian doctrinal tradition: it need not be a philosophical sin to be theologically eclectic. So while I do think that, starting from an interpretation such as Mariña's, a plausible case can be made that Kant articulates a philosophical anthropology congruent in its main points with a Christian theological anthropology, this kind of larger account still cannot be fully identified with that of a single historically articulated theological tradition such as Lutheran, Calvinist, or Catholic. With regard to the particular function of a concept such as grace within that anthropology, however, one may be able to locate Kant's views more successfully on such a theological map-with the proviso that the orientation for locating him on any particular theological map may itself be a function of the theological horizon of the one using the map.

One might then argue that the differences between the at least "quasiCatholic" Kant of Mariña and the "Pelagian" Kant of Michalson, Wolterstorff, et al. result primarily from differences in the theological horizon from which Kant is being read by each interpreter. A case of this kind seems all the more plausible if one recognizes that the theological perspective from which Mariña reads Kant has striking resemblances to two important 20th-century articulations of Catholic theology that bear upon the anthropological import of grace: (1) the transcendental Thomism that traces its origin to the efforts of Joseph Maréchal to engage Kant's critical philosophy, not primarily as a representative form of subjectivism, but as a serious conversation partner with which to engage the work of Thomas Aquinas; ${ }^{21}$ and (2) the movement of la nouvelle théologie that in the mid-20th century challenged the then regnant Catholic theological paradigm of the relation between grace and nature. The particular horizon from which Mariña reads Kant's "general concept of grace" is closely aligned with the horizon of grace that Karl Rahner delimits in terms of his notion of a "supernatural existential" as a "real, ontological and unexacted ordination to God." ${ }^{22}$ For her part, Mariña relates the universality of grace to "the unconditioned worth of all rational beings, and hence, to the moral law, $" 23$ and then takes such universality to be a mark of the gratuity with which grace is bestowed:

When we say that grace is freely given, what we mean is that it is not something owed to us in virtue of some special characteristic we possess setting us apart from

"The Philosophy of Immanuel Kant," in The Catholic Encyclopedia (1907-1912), http://www.newadvent.org/cathen/08603a.htm (accessed July 16, 2009).

${ }_{21}$ See Rossi, "Reading Kant through Theological Spectacles" 115-17.

22 Karl Rahner, "The Theological Concept of Concupiscientia," in Theological Investigations 1, trans. Cornelius Ernst (Baltimore: Helicon, 1965) 376-77.

${ }^{23}$ Mariña, "Kant on Grace" 385. 
others, or in virtue of something we do making us special. Our actions do not constrain God to confer any good upon us or to enter into relation with us. The divine/human relationship is established by God with us before any act on our part, and this means that all that we can do is to be receptive of God's grace. ${ }^{24}$

Two features of Mariña's treatment are worth noting. First, she draws attention to the universal function of grace in constituting the unconditioned moral worth of humans whereby God establishes a relation with us "before any act on our part." Second, she argues that grace is operative in the relational context constitutive of human moral agency so that "the very possibility of our doing good rests on grace." 25 These features taken together resemble a key contention made both by proponents of la nouvelle théologie and by transcendental Thomists. On their part, they both argued for the primacy of understanding grace as a constantly offered invitation of relationship with the divine that functions at the level of the fundamental human dynamisms of knowledge and desire. ${ }^{26}$ They maintained that such a relational construal of grace comports better with an integral and holistic understanding of the human than did the then dominant neo-Thomist emphasis on grace as a "transient elevating motion" that works upon particular moments of human activity within a bifurcated account of the human. ${ }^{27}$

I point out the affinities between Mariña's interpretation of Kant's account of grace and a notion such as Rahner's "supernatural existential" not primarily to engage in discussion about the appropriateness of the latter notion as an element within a Catholic theology of grace, but rather to stimulate an exploration of the dynamics that enter into reading Kantor any philosopher for that matter-from a particular theological horizon, be it explicit or implicit. I hope that I have already made a case for taking seriously the possibility that-to put it in the broadest possible termsgiven their historical differences with respect to theological anthropology, Catholics are likely to read Kant differently than Calvinists, for instance, and that they are each in turn likely to read him differently than Lutherans. It is also likely that any of these readings will, in turn, display differences from those conducted within the immanent frame of a resolutely secularist horizon with its putatively atheological anthropology.

These differences, however, do not seem simply to lie athwart these larger distinctions among Christian theological traditions but also follow other fault lines within and across these traditions. Thus it is likely that, to

${ }^{24}$ Ibid. 383 ; see also the passage on 384 cited in $n .16$ above.

25 Ibid. 399.

${ }^{26}$ In private correspondence, Mariña has confirmed this affinity between her reading of Kant on grace and the views of a theologian such as Rahner.

27 Gerald A. McCool, S.J., From Unity to Pluralism: The Internal Evolution of Thomism (New York: Fordham University, 1989) 206. 
an Arminian, Mariña's defense of Kant against Pelagianism would seem unnecessary; while to a neo-Thomist convinced of Kant's ineradicable subjectivism, as well as to a Barthian for whom such philosophical speculation borders on the idolatrous, such a defense would be hopelessly misguided. As the differences between Mercier and Mariña indicate, moreover, "Catholic" readings of Kant range from the Kant who functions as an iconic "adversarius" of the neo-Scholastic manuals, to the Kant who is the object of the thoroughgoing scholarship of a Giovanni Sala or a François Marty, to the Kant who is a central interlocutor for the philosophical theology of a Richard Schaeffler. ${ }^{28}$

Though there are many different faces to such a "Catholic Kant," it may yet be possible to discern under some of them a common set of concerns

${ }^{28}$ There is notable European Catholic scholarship on Kant that has moved significantly beyond an earlier neo-Scholastic/neo-Thomist dismissive polemic. Giovanni Sala has produced important historical/textual studies of Kant (Kant und die Frage nach Gott: Gottesbeweise und Gottesbeweiskritik in den Schriften Kants [Berlin: de Gruyter, 1990]), as well as work that engages Kant critically from the perspective of Lonergan (Das Apriori in der menschlichen Erkenntnis: Eine Studie über Kants Kritik der reinen Vernunft und Lonergans Insight [Meisenheim am Glan: A. Hain, 1971]; and Lonergan and Kant: Five Essays on Human Knowledge [Toronto: University of Toronto,1994]). Richard Schaeffler has constructively engaged Kant's philosophy of religion and the Kantian question of hope: Was Dürfen wir Hoffen: Die katholische Theologie der Hoffnung zwischen Blochs utopischem Denken und der reformatorischen Rechtfertigungslehre (Darmstadt: Wissenschaftliche Buchgesellschaft, 1979); Religionsphilosophie (Freiburg: K. Alber, 1983). In France, François Marty (L'homme, habitant du monde: À l'horizon de la pensée critique de Kant [Paris: H. Champion, 2004]) and Henri d'Aviau de Ternay (La liberté kantienne: Un impératif d'exode [Paris: Cerf, 1992]; Traces bibliques dans la loi morale chez Kant [Paris: Beauchesne, 1986]) have offered sympathetic readings of key metaphysical and moral motifs in Kant's philosophy. Perhaps the most significant rereadings of Kant with respect to Catholic philosophy and theology have emerged in Germany from the work of Aloysius Winter (Der andere Kant: Zur philosophischen Theologie Immanuel Kants [New York: Olms, 2000]), in a collection of essays edited by François Marty and Friedo Ricken (Kant über Religion [Stuttgart: Kohhammer, 1992]), and in two volumes edited by Norbert Fischer (Kants Metaphysik und Religionsphilosophie [Hamburg: Meiner, 2004] and Kant und der Katholizismus: Stationen einer wechselhaften Geschichte [Freiburg: Herder, 2005]). At the presentation of the latter volume, Fischer delivered a lecture provocatively titled Müssen Katholiken weiterhin Furcht vor Kant haben?: Kants Philosophie als "ancilla theologiae" (Eichstätt: Universitätsverlag Kastner 2005). Important recent scholarship is exemplified in Ulrich Lehner's examination of the theological context of Kant's work and its Catholic reception, particularly prior to the placing of the Critique of Pure Reason on the Index in 1827 (Kants Vorsehungskonzept auf dem Hintergrund der deutschen Schulphilosophie und -theologie [Boston: Brill, 2007]). For an overview of the reception of Kant within Catholic philosophy and theology in the United States, see Philip Rossi, S.J., "Die Bedeutung der Philosophie Immanuel Kants für die gegenwärtige katholische Theologie in den Vereinigten Staaten von Amerika," in Kant und der Katholizismus 441-60. 
that shape the interrogation of Kant's texts. There may be a discernible set of common "Catholic questions" that guide such readings, even when those who ask them take Kant's text to yield quite different, even conflicting, answers. These concerns, I believe, constitute a kind of "Catholic theological interrogation" of Kant's anthropology, i.e., his account of how the human, as the unique juncture of nature and freedom, stands with relation to the divine. I suspect that the most important connecting thread through all these concerns may be drawn though questions about grace and its functioning in, and as the dynamic of, the divine/human relationship, but I will not try to show that here. Instead I will, first, propose what I see as three of the focal questions for such a theological interrogation. Second, I will briefly explore how different visages of a "Catholic Kant" emerge in consequence of these questions. Finally, I will conclude by suggesting why the aspects of Kant's treatment of "how the human stands with respect to the divine" that get highlighted from such a "Catholic interrogation" are worthy of further discussion both from the side of Kant scholarship and from that of theological inquiry.

\section{A CATHOLIC INTERROGATION OF KANT}

The focal questions for a "Catholic interrogation" of Kant, I suggest, coordinate major elements of Kant's account of the human with a set of concerns historically characteristic of Catholic theology. The first question pertains to the capacity of the of human conscience, through its deliverances about moral truth and responsibility, to mark a reliable path to the acknowledgment of the divine. On Kant's side, this question bears globally upon his understanding of human moral agency, but more specifically upon his key claim that "morality thus inevitably leads to religion," which I take to include his much controverted "moral argument for God." 29 On the Catholic side this question arises in its most general form from a commitment to the mutual congruence of faith and reason and, more

29 The claim that "morality thus inevitably leads to religion" is one that Kant makes in his preface to Religion within the Boundaries of Mere Reason, trans. and ed. George Di Giovanni, under the title, Religion and Rational Theology, ed. Allen W. Wood and George Di Giovanni, Cambridge Edition of the Works of Immanuel Kant (New York: Cambridge University, 1996) 59. A full overview of Kant's "moral argument," which he articulates in a number of texts, can be found in Allen W. Wood, Kant's Moral Religion (Ithaca, N.Y.: Cornell University, 1970). Two helpful brief treatments of the major concerns and arguments in Kant's treatment of religion are Allen W. Wood, "Rational Theology, Moral Faith, and Religion," in The Cambridge Companion to Kant, ed. Paul Guyer (New York: Cambridge University, 1992) 395-416; and Frederick C. Beiser, "Moral Faith and the Highest Good," in The Cambridge Companion to Kant and Modern Philosophy, ed. Paul Guyer (New York: Cambridge University, 2006) 588-629. 
particularly, from claims about the capacity of human reason to discern truth in the form of "natural law" - and, from the discernment of that truth, for a person to be then rendered open to a fully graced relation with God. The second question concerns the extent to which there is an inherently social dimension to the ultimate destiny of humankind. On Kant's side, this question bears upon his notion of the human moral community as a "kingdom of ends" and the role this community plays in the attainment of human moral destiny. It is a question about the answer(s) that Kant finally gives to the third of his famous questions, transformed into its plural form: "For what may we hope?" On the Catholic side, this is a question about both eschatology and ecclesiology, one that might be provocatively posed in dialogue with Kant as a question about the relationship between "the communion of saints" and "the kingdom of ends." The third question concerns Kant's understanding of (the order of) creation and of the fundamental character of the divine difference from and relation to the human. It bears upon Kant's construal of causality, and upon his distinction between regulative and constitutive uses of the notions of "God," "world," and "self/soul." On the Catholic side, this is a question not only about the doctrine of creation but also about the capacity of particular realities in the order of creation to function as efficacious signs of divine reality-i.e., a question about the possibility of affirming the reality of the world and of what takes place in it as sacramental. ${ }^{30}$

I will here pursue only the first line of questioning, in part because of constraints of space, but also because this line of questioning reveals some of the different "faces" of Kant discernible in Catholic readings of his texts. In his essay on "The Two Critiques of Kant," Mercier depicts one of the more familiar faces, a portrait by no means confined only to Catholic readings of Kant: this is Kant, the moral subjectivist, who is woefully mistaken in his confidence that, by closing the speculative path to an affirmation of God, "critique" provides what is needed to secure passage to God along the route of moral certainty. Mercier depicts one variant of a type of Kantian "face" that emerges from what has long been a standard account of Kant's ethics given by friend and foe alike.

This account has at its core some version of three claims about Kant's ethics:

(1) Inasmuch as it is concerned with the formal features of human rationality, it does not require us to have a notion of human nature or to develop a moral anthropology.

30 This last question is the one for which I think it would be most difficult to extract an unambiguously Catholic answer from Kant's texts. 
(2) Inasmuch as it is deontological and concerned with what is "right," it stands as the paradigmatic contrast to teleological ethics, concerned with what is "good," such as that found in Aristotle.

(3) Inasmuch as it is concerned with the moral integrity of the individual choices I make as a moral agent, it requires neither the development of an account of moral virtue nor a social philosophy.

While these three claims may not seem to have direct bearing upon the truth or adequacy of Kant's claim that "morality leads ineluctably to religion," anyone versed in the ways Catholic theology has typically treated "natural law" as a source of reliable moral knowledge will recognize a number of salient features in these claims that set Kant's ethics over against claims about moral agency and moral knowledge as typically framed by a natural law perspective. In place of an understanding of practical reason as a firmly rooted "participation . . . in the wisdom of the divine Creator and Lawgiver," Kant seems to posit an understanding of "rationality" as a formal, abstract procedure that is not affected by the specifics of our human condition: I make decisions as a moral agent abstracted from the particularities of this time and this place, as a member of a timeless "intelligible world." Posed in these terms, Kant's account of morality seems quite literally abstracted from the flesh and blood reality of human beings who have to make moral decisions in the concrete circumstances of daily life; it is the ethics of a cold and stern Prussian taskmaster, suited more to the disembodied rationality of angels than to living and breathing human beings. Even more damaging and damning, the formality of Kant's ethics leads some to hold that it lies behind the pleadings of the Eichmanns of the world: "I was only carrying out my orders," or, in the powerful description of Iris Murdoch, that it leads to the very antithesis of a Christian moral agency:

How recognizable, how familiar to us, is the man so beautifully portrayed in the Groundwork, who confronted even with Christ turns away to consider the judgment of his own conscience and to hear the voice of his reason.... This man is with us still, free, independent, lonely, powerful, rational, responsible, brave, the hero of so many novels and books of moral philosophy. ... He is the ideal citizen of the liberal State, a warning held up to tyrants. ... Kant's man had already received a glorious incarnation nearly a century earlier in the work of Milton: His proper name is Lucifer. ${ }^{32}$

I will not dispute the view that this portrayal of Kantian moral agency has been highly influential as an icon of modernity and enlightenment at

${ }^{31}$ Pope John Paul II, Veritatis splendor no. 40.

${ }^{32}$ Iris Murdoch, The Sovereignty of Good (New York: Schocken, 1971) 80. Murdoch's later treatment of Kant in Metaphysics as a Guide to Morals (New York: Penguin, 1982) offers a more complex and sympathetic account of his view of moral agency than is represented in this quotation. 
many levels of European and North American culture during the last two centuries; nor will I set forth here the reasons why I think that this portrayal does not, in fact, accurately present Kant's own more complex view of moral agency or do justice to the richness of his understanding of "reason." 33 Of greater import, for my purposes, is the fact that this portrayal of the Kantian moral agent, as well as the three claims of the standard account that lend it plausibility, are themselves representative of a larger account of Kant's critical enterprise. Recent scholarship has suggested that this reading of his enterprise is problematic in at least two major respects: first, it takes anthropological, teleological, and social considerations to be, at best, marginal to the goals and scope of that project; second, it permits or presumes a bifurcation of theoretical and practical uses of reason by discounting or dismissing as ineffective Kant's continual assertions of the unity of the reason that engages the world both theoretically and practically.

I think it is easy to see why the lineaments of such a disembodied, disconnected, autonomously self-sufficient Kantian moral subject were readily taken by a revived and renewed Thomism to be representative of the most problematic features of modern philosophy. These were features from which one could trace the progression by which the Cartesian cogito and the dualism of the res extensa and the res cogitans culminated in even more recalcitrant Kantian dualisms: the external one of phenomenon and noumenon, matched by the internal one of apperception and autonomy in the Kantian subject. Neo-Thomism certainly grappled with dualisms and dualities within its own enterprise - a number of which, significantly, were at the core of the controversy over the account of grace proposed by $l a$ nouvelle théologie. Even so, it could nonetheless claim advantage over all the varied subjectivisms of modern philosophy by virtue of two of his core features: its studied and intentional bypassing of the Cartesian cogito as starting point for philosophical inquiry, as well its reaffirmation of an epistemic realism grounded on an Aristotelian-Thomist dynamism of potency and act. In their respective contexts, the standard philosophical reading of Kant as the inheritor of an enclosed Cartesian subjectivity and

${ }^{33}$ Two useful alternative readings of Kantian agency can be found in Jeanine Grenberg, Kant and the Ethics of Humility: A Story of Dependence, Corruption, and Virtue (New York: Cambridge University, 2005); and G. Felicitas Munzel, Kant's Concept of Moral Character: The "Critical" Link of Morality, Anthropology, and Reflective Judgment (Chicago: University of Chicago, 1999); Susan Neiman, The Unity of Reason: Rereading Kant (New York: Oxford University, 1994); and Onora O'Neill, Constructions of Reason: Explorations of Kant's Practical Philosophy (New York: Cambridge University, 1989) have each proposed ways of understanding Kant's notion of reason that attend to more than the formal features that have characterized much prior Kant interpretation. 
the resolute a- and anti-modernity of much neo-Thomism made them a good adversarial match for each other.

Recent historical and interpretive scholarship has questioned some key elements of these accounts of Kant's moral philosophy and of his critical enterprise which, at least in English-language discussions, have enjoyed interpretive preeminence for much of the 20th century. This scholarship has started to highlight a number of elements previously considered marginal within the larger critical enterprise and to reconsider the shape and role of moral philosophy within that larger project. Thus, in contrast to the standard account in which Kant's ethics is construed in terms of a formality that abstracts it from considerations of teleology, anthropology, and virtue, recent work on Kant's ethics, particularly by attending to the larger context in which Kant himself places his writings on morality, has argued that these putative "un-Kantian" notions do, in fact, play a key role in his account of the structure and dynamics of human moral life. ${ }^{34}$ With regard to Kant's larger critical enterprise, a renewed interest in the function of the Critique of the Power of Judgment, ${ }^{35}$ as well as in the bearing of Kant's other writings of the late 1780 s and 1790 s upon his own developing understanding of critique, has started to displace the Critique of Pure Reason as the primary interpretive lens for reading the entire project. As crucial as that initial critical volume remains, it can no longer be read as some kind of master blueprint guiding the construction of even such major components as the two later works Kant also titled Critique. One result of such a reassessment has been to lessen the plausibility of the picture of "Kant the adversary" that had been a staple of neo-Scholastic manuals and textbooks through at least the middle of the 20th century.

A foreshadowing of this interpretive shift in a Catholic reading of Kant can be found by comparing the treatment James Collins offered in $A$ History of Modern European Philosophy (1953) ${ }^{36}$ with the one he provided in The Emergence of Philosophy of Religion (1967). ${ }^{37}$ Collins,

${ }^{34}$ Allen Wood has been a key figure in effecting such a shift. Among other major contributors are Marcia Baron, Jeanine Grenberg, Paul Guyer, Barbara Herman, Robert Louden, G. Felicitas Munzel, Susan Neiman, Onora O'Neill, Roger Sullivan, and Richard Velkley. The historical studies of Frederick Beiser and John Zammito have also been important, as has been Alan Donagan's The Theory of Morality (Chicago: University of Chicago, 1977), which argued that Kant and Aquinas stand in far closer affinity in their understanding of the first principle of the moral law than many of the then-standard accounts of either thinker recognized.

${ }^{35}$ This is the translation given to the title of Kant's 1790 Kritik der Urteilskraft in The Cambridge Edition of the Works of Immanuel Kant, trans. Paul Guyer and Eric Matthews (New York: Cambridge University, 2000).

${ }^{36}$ Milwaukee: Bruce, 1953.

${ }^{37}$ New Haven, Conn.: Yale University, 1967. 
arguably one of the most erudite scholars and influential teachers in the mid-20th-century Catholic philosophical community, wrote the former "primarily as a textbook for students who have some acquaintance with Scholastic philosophy," 38 and in which "a critical appraisal is also made, from the Thomistic standpoint, of some of the particular arguments offered by the philosopher in question." ${ }^{39}$ In that work, he makes the unsurprising summary conclusion, clearly in accord with the standard lines of neo-Scholastic criticism, that "Kant reduced the content of religion to morality." ${ }^{40}$ In the latter work, written not as a textbook, but as a substantial historical interpretation (of which Collins was a master), his aim was to investigate "the insistence on the part of many modern philosophers that their inquiry into our knowledge of God was only a part of a larger inquiry into the religious relationship between man and God." ${ }^{41}$ His chapter titled "Kant's Moral Radication of Religion" 42 explores crucial ways in which he finds, contrary to the conclusions of standard anti-Kant polemic, Kant's account of the relationship between morality and religion to be, in intent and result, clearly nonreductive. At the time of its publication, Collins's work was pioneering both for its nonreductivist reading of Kant in matters of religion and for the constructive way it engaged that account from a philosophical perspective shaped by Catholic theological concerns. ${ }^{43}$ Yet, perhaps as a result of a deeply entrenched view of Kant that saw him as the lineal and logical inheritor of a self-enclosed Cartesian subjectivism, Collins's work seems to have had little immediate impact on altering the way Kant was read either by Kant scholars and philosophers of religion in the secular academy or by Catholic philosophers and theologians.

Although the landscapes both of Kant scholarship and of Catholic philosophical and theological engagement with Kant have altered considerably since Collins's The Emergence of Philosophy of Religion, the full lineaments of this new philosophical picture of Kant, the critical project, and the anthropological issues that guide its trajectory have yet to emerge. This is due in part to the fact that so far it remains an uncompleted mosaic to which workers from various philosophical and theological vantage points continue to make contributions. A part of the mosaic that has started to take shape is its retrieval of the social dimensions of Kant's account of hope, a dimension with crucial bearing upon how Kant construes the cultural, political, and religious dynamics that provide the conditions for

Ibid. iv.

pean Philosophy iii.

Collins, The Emergence of Philosophy of Religion vii.

Ibid. 129-66.

${ }^{43}$ See also the final chapter, "Tasks for a Realistic Theism," in The Emergence of Philosophy of Religion 423-91. 
fulfillment of this hope. ${ }^{44}$ As I suggested earlier, this social reading of Kant offers a number of points for interrogation from the side of ecclesiology and eschatology: How does Kant construe the destiny of humankind and the roles we, both individually and socially, need to play in it? Is there (conceptual) space for grace or divine providence to play a role in Kant's account of the attainment of human destiny? ${ }^{45}$ How does Kant's account of these matters comport with the various ways Christian theology has construed the pathway to the attainment of human destiny? These are not new questions, but $\mathrm{I}$ think that there is at least a twofold reason for raising them again. First, as I hope discussion of Mariña's analysis of Kant's alleged Pelagianism has shown, it may prove useful to frame these questions with an explicit awareness of the theological horizons that are brought to the interrogation. One can readily miss the possibility that Kant may have a universal concept of unmerited grace if all one is looking for is the grace that brings about forensic justification. Second, the emerging new profile of Kant's (moral and religious) anthropology suggests that we may receive answers different from the ones we previously took them to have-answers that, however they stand with respect to doctrinal orthodoxy, may nonetheless merit serious theological attention.

\section{TRAJECTORIES FOR THE FUTURE}

This shift on the side of philosophical interpretations of Kant, at least with regard to his moral philosophy and its relationship to his accounts of religion, society, and culture, has been intriguing to me on several levels. I have found myself participating in a shifting of horizons of Catholic read-

${ }^{44}$ In rereading of the role of hope in Kant's work, I have observed that recent commentators differ from the standard view that sees him as an exemplar of Enlightenment optimism. Wood and Neiman both consider it important to distinguish Kant's account of hope from various forms of optimistic belief in the inevitability of "progress," particularly in matters of human moral life and conduct. Wood, for instance, remarks: "The only hope Kant thinks we can entertain is for an endless, uncertain, painful (and occasionally interrupted) progress from bad toward better" (Kant's Ethical Thought [New York: Cambridge University, 1999] 320). And Neiman, commenting on the "minimalist" character of the "signpost" Kant erected as support for hope in moral progress, observes: "Still, the poverty of Kant's example should forever give the lie to the myth of Enlightenment optimism. If the only sign of hope he could find to sustain him was the hope felt by distant observers contemplating the French Revolution, Enlightenment expectations were slight indeed" (Moral Clarity: A Guide for Grown-up Idealists [Orlando: Harcourt, 2008] 278-79).

${ }^{45}$ A useful point of reference from which to start such a discussion can be found in Pauline Kleingeld, "Nature or Providence? On the Theoretical and Moral Importance of Kant's Philosophy of History," American Catholic Philosophical Quarterly 75 (2001) 201-19. 
ings of Kant: first, as a long-time student of Kant's work, but also as one whose initial philosophical formation was under the tutelage of a faculty influenced by the Maréchalian heritage and while Karl Rahner was among the most influential Catholic theologians; second, as a faculty member for over three decades in a large department of Catholic theology in which I have regularly found Kant-or at least the putative heritage of Kantlooming large in the background of discussions of key theological issues that have occupied both Catholic and Protestant theology for the last two centuries. My role in that theological context is often to remind students and colleagues - and myself-of the importance of attending to distinctions, the task that Robert Sokolowski has characterized as "the method of philosophy." ${ }^{46}$ One of the distinctions I regularly invoke is that between what theologian (or theological school) X took Kant to hold on topic Y, and what, on the basis of his texts and their contexts, Kant, in fact, held on topic Y. The former, of course, is often of greater importance historically - a case in point being Mercier's reading of Kant, as well as that of much of the neo-Thomist tradition: the views of the Kant against whom they argued bear, in far too many instances, a tenuous relation to the views that can be most plausibly construed from his texts, particularly when those texts are read with attention to Kant's own historical context. Still, it was the reading of Kant as relativist and subjectivist that dominated discussion. It is also well to remember that the neo-Thomist tradition has hardly been alone in reading Kant to suit its own larger purposes, whether theological or philosophical. The Kant of the mid-20th-century AngloAmerican analytic tradition is starting to become just as quaint with respect both to more recent Kant scholarship and to various philosophical and theological postmodernisms.

How, then, do matters currently stand regarding current Catholic interrogations of Kant? Trends in recent Kant scholarship have suggested that Kant's anthropology can legitimately be read in ways considerably more "friendly" to Catholic theological concerns than were the readings of Kant typical of Catholic philosophy and theology for much of the 20th century. ${ }^{47}$ As already noted, these more recent readings of Kant show considerable congruence with the kind of theological anthropology articulated by

${ }^{46}$ Robert Sokolowski, "The Method of Philosophy: Making Distinctions," Review of Metaphysics 51 (1998) 515-32.

${ }^{47}$ Recent efforts to read Kant as "theologically friendly" from Evangelical perspectives are found in the work of Chris L. Firestone, Nathan Jacobs, and Stephen Palmquist. Firestone has most recently published Kant and Theology at the Boundaries of Reason (Aldershot: Ashgate, 2009); he and Jacobs authored In Defense of Kant's Religion (Bloomington: Indiana University, 2008); and he and Palmquist edited Kant and the New Philosophy of Religion (see n. 3 above). See also Palmquist Kant's Critical Religion (Aldershot: Ashgate, 2000). 
theologians in the tradition of "transcendental Thomism," who read both Thomas and Kant in terms of an Augustinian dynamic orienting and ordering our (finite) human capacities along a trajectory toward the divine. But it is important to note that these readings also comport well with some of the larger Catholic anthropological themes of which that specific tradition is just one articulation. ${ }^{48}$ Thus a Kantian anthropology in which the social character of human activity is deeply inscribed in all its uses is more resonant than dissonant with Catholic affirmations that our human reality is inherently social-and all the more so inasmuch as they both can be understood to take that social character to be a fundamental correlate to the respect due the dignity of each human person. If Kant uses his basic claim that "morality leads ineluctably to religion" to construct a subtle account of how a steadfast moral life implicates recognition of the reality of a God who stands over against the vicissitudes of human life, Catholics have in Kant an intellectual ally for their projects. For instance, a sympathetic Catholic reading of Kant could open up possibilities for an extensive constructive engagement with John Paul II's repeated vigorous affirmations that "moral conscience does not close man within an insurmountable and impenetrable solitude, but opens him to the call, to the voice of God." 49 It might also attune one to the Kantian resonance within the intercession from the liturgy of Good Friday in which the church prays that "those who do not believe in God . . . may find him by sincerely following all that is right." 50

This interpretive convergence suggests a point for further investigation. Although there seem to be a number of matters on which a transcendental Thomist reading of Kant chronologically anticipates some of the shifts that

${ }^{48}$ For an initial sketch of how Kant's anthropology might serve as resource for a Catholic theology of grace in the context of postmodern discourse and culture, see Philip J. Rossi, S.J., "Finite Freedom, Fractured and Fragile: Kant's Anthropology as Resource for a Post-modern Theology of Grace," Philosophie et Théologie: Festschrift Emilio Brito, ed. Ėric Gaziaux (Leuven: Peeters, 2007) 47-60.

${ }^{49}$ Veritatis splendor no. 58. The passage, which quotes an address John Paul II originally delivered in 1983, ten years before the publication of Veritatis splendor, continues: "Moral conscience does not close man within an insurmountable and impenetrable solitude, but opens him to the call, to the voice of God. In this, and not in anything else, lies the entire mystery and the dignity of the moral conscience: in being the place, the sacred place where God speaks to man" (see John Paul II, address to a general audience, August 17, 1983, http://www.vatican.va/holy_father/ john_paul_ii/audiences/1983/documents/hf_jp-ii_aud_19830817_it.html [accessed September 23, 2009]); see also Fides et ratio no. 25 where John Paul affirms "the search for truth which looks to the good which is to be performed."

${ }^{50}$ The Roman Missal: Sacramentary, English translation prepared by the International Commission on English in the Liturgy (revised according to the second typical edition of the Missale Romanum [1975], Good Friday: Celebration of the Lord's Passion, Intercessory Prayers VIII: "For those who do not believe in God." 
seem to be taking place in Anglo-American interpretation of Kant's anthropology and its role in his account of human reason, it is highly unlikely that the latter was influenced by the former. If, however, it turns out that this more recent philosophical reading of Kant does more adequately represent "what Kant, in fact, held," one might ask whether the transcendental Thomists' anticipation of this reading might have been a consequence of the theological orientation that had a role in their "interrogation" of Kant. Might their reading of Kant have been an instance in which a theological frame of reference offered a vantage point better positioned to note some matters of philosophical import? I believe that a similar question can be posed to the interpretations of Kant provided by Karl Barth and H. Richard Niebuhr, two of the great Protestant theologians of the 20th century, who on certain key points seem to have succeeded better than many of their philosophical contemporaries in getting Kant "right."

Yet, just as a more theologically receptive reading of Kant has started to gain more prominence in philosophical discussions, Catholic theology seems to be reassessing — and, in some quarters, moving away from-transcendental Thomism and other "critical correlationist theologies" that, in various ways, sought to retrieve key aspects of the methods and forms of modern intellectual inquiry and put them to positive theological use. As Anthony Godzieba has noted, theological approaches such as "Hans Urs von Balthasar's work . . . , the Radical Orthodoxy industry, and the philosophical theology developed under the influence of Jacques Derrida, most notably the work of Jean-Luc Marion and John Caputo's 'religion without religion" have become "major rivals" to the style of Catholic theology typical of the decades immediately following Vatican II. ${ }^{51}$ Godzieba observes that all three of these approaches are "critical or even disdainful of any kind of correlation between the "modern world' and Catholicism" and that "the obvious thread that ties these diverse styles together is their systematic and fundamentally negative evaluation of modernity." ${ }^{52}$ Not surprisingly, as a key figure of modernity, Kant is included in that negative evaluation and often reinstated in the role of (arch)adversarius.

Does this apparent shift in the Catholic theological horizon, then, signal the end of "friendly" Catholic interrogation of Kant? I hope not, but there surely are some who welcome a return to strongly adversarial styles of dealing with Kant-as well as with the host of other thinkers who have shaped "modernity." The sharp-edged polemic against modernity used by

${ }^{51}$ Anthony Godzieba, "Incarnation, Theory, and Catholic Bodies: What Should Post-postmodern Catholic Theology Look Like?" Louvain Studies 28 (2003) 217-31.

52 Ibid. 220. 
the proponents of Radical Orthodoxy is witness to this. In contrast, a document such as John Paul II's encyclical Fides et ratio exhibits a more complex stance with respect to its view of theological engagement with the various strands of modern and contemporary philosophy. Its endorsement of a modest philosophical pluralism stands side by side with the more formal cataloging of the pernicious "isms" of modernity reminiscent of an earlier style of neo-scholasticism. ${ }^{53}$ This is itself one index of the fact that, for more than two centuries, there has been more than one Catholic style for interrogation of modern philosophy and a hesitant recognition that the tensive interplay among these styles has long marked official and unofficial Catholic responses to modernity and its aftermath. While these various styles all have their particular value, I do think there is one that offers a particularly wide range of possibilities for yielding results of value for both philosophical and theological inquiry. I see this style at work in authors such as Charles Taylor and Louis Dupré for whom the "catholicity" of their interrogation functions in terms of a confidence in the universal abundance of God's grace; it is a style that is generously open to the possibility that, even in the darkest, most unpromising, and most resistant regions of the mind, heart and spirit of modernity - and postmodernitythe Spirit of God is ceaselessly at work.

${ }^{53}$ For the endorsement of a limited philosophical pluralism, see Fides et ratio nos. 74-76; for the cataloging of various "isms" see nos. 46, 54-55, 86-90. 